\title{
Prevalence of anti-herpes simplex virus type 1 among dental students of Birjand University of Medical Sciences, Iran, 2017-2018
}

\author{
Parvin Parvaie ${ }^{(D)}$, Saideh Ebrahimian Baghan ${ }^{\left(D^{2}\right.}{ }^{2}$, Mahmood Zardast $^{\left({ }^{3}\right.}{ }^{3}$, Gholamreza \\ Sharifzadeh ${ }^{4}{ }^{4}$, Freshteh Osmani ${ }^{5 *}$
}

\begin{abstract}
Herpes simplex virus is considered one of the most common human infections in most parts of the world, among which, herpes simplex virus 1 (HSV-1) is one of the most important human pathogenic viruses that cause numerous skin and oral lesions. Practitioners of the dental profession and related fields are in close contact with numerous patients referring to dental clinics and are at risk of cross-infection. Regarding this, one of the infections that dental professionals are exposed to is herpes simplex virus infection. This study aimed to evaluate the level of HSV1 antibody among dental students of Birjand in 2018-2019. This crosssectional study was performed on 100 dental students of Birjand University of Medical Sciences, Iran. After obtaining informed consent, a peripheral blood sample $(5 \mathrm{ml})$ was collected from participants and the presence of anti-virus antibody was examined using an Anti-Herpes-1 IgG kit with the enzyme-linked immunosorbent assay. It was revealed that $41 \%$ of the subjects had anti-herpes type 1 antibodies. Based on data analysis, the prevalence of HSV1 antibody was higher in pre-clinical and clinical level than in basic science; however, there was no significant relationship between students' educational level and antibody prevalence.
\end{abstract}

Keywords: Cross-infection, Dental students, HSV1 antibody

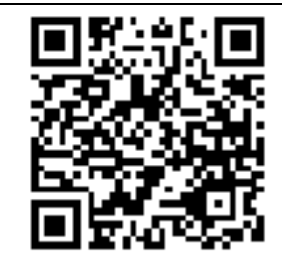

Citation: Parvaie P, Ebrahimian Baghan S, Zardast M, Sharifzadeh Gh, Osmani F. [Prevalence of anti-herpes simplex virus type 1 among dental students of Birjand University of Medical Sciences, Iran, 2017-2018]. J Birjand Univ Med Sci. 2021; 28(3): 296-301. [Persian]

DOI http://doi.org/10.32592/JBirjandUnivMedSci.2021.28.3.108

Received: September 19, 2020

Accepted: January 14, 2021

\footnotetext{
${ }^{1}$ Dentistry Clinical Research Development Unit, School of Dentistry, Birjand University of Medical Sciences, Birjand, Iran

${ }^{2}$ Dentistry Student Research Committee, Birjand University of Medical Sciences, Birjand, Iran

${ }^{3}$ Medical Toxicology and Drug Abuse Research Center, Birjand University of Medical Sciences, Birjand, Iran

${ }_{5}^{4}$ Social determinants of health research center, Faculty of Health, Birjand University of Medical Sciences, Birjand, Iran

${ }^{5}$ Infectious disease Research center, Birjand University of Medical Sciences, Birjand, Iran
}

* Corresponding author: Infectious disease Research center, Birjand University of Medical Sciences, Birjand, Iran

Tel: +985632381715

E-mail: f.osmani@bums.ac.ir 


\title{
فراوانى ضد ويروس هريس سيميلكس نوع ادر بين دانشجويان دندانيزشكى دانشكاه علوم يزشكى

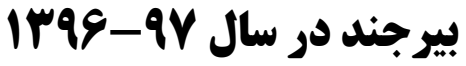

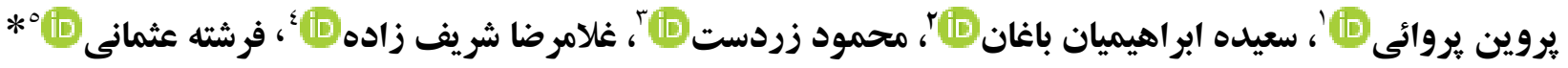

\section{جمكيله}

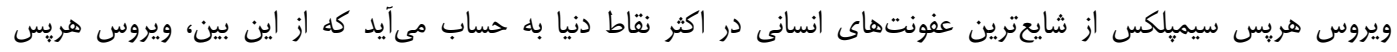

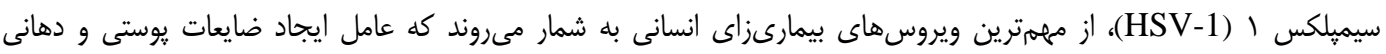

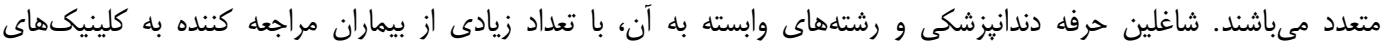

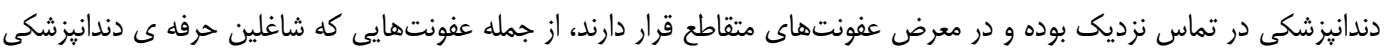

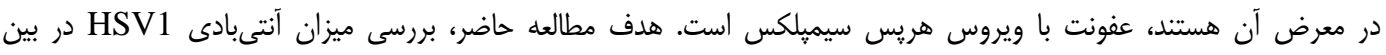

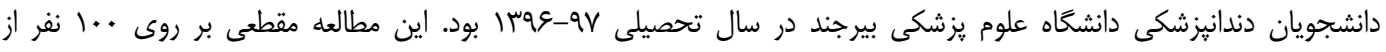

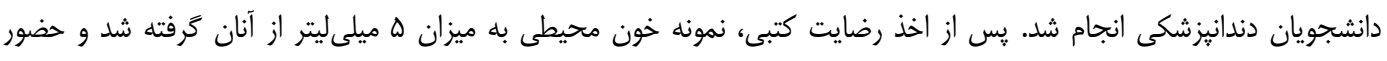

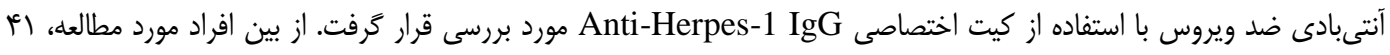

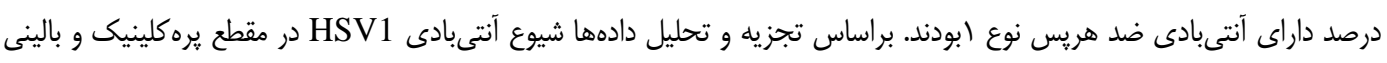

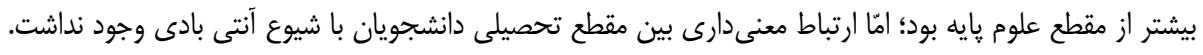

$$
\begin{aligned}
& \text { وازههاى كليدى: عفونت متقاطع، دانشجويان دندانيزشكى، آنتىبادى HSV1 }
\end{aligned}
$$

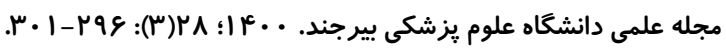

$$
\begin{aligned}
& \text { دريافت: }
\end{aligned}
$$

$$
\begin{aligned}
& \text { ' واحد توسعه تحقيقات بالينى دندانيزشكى، دانشكده دندانيزشكى، دانشكاه علوم يزشكى بيرجند، بيرجند، ايران }
\end{aligned}
$$

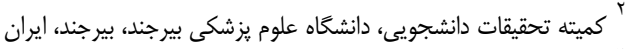

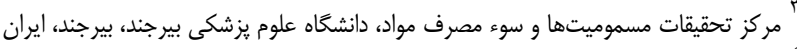

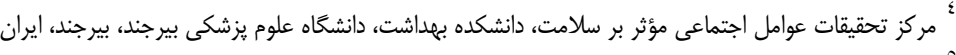

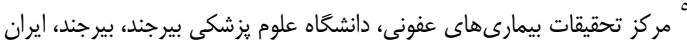

$$
\begin{aligned}
& \text { *نويسنده مسئول: مركز تحقيقات بيمارى هاى عفونى، دانشكاه علوم يزشكى بيرجند، بيرجند، ايران }
\end{aligned}
$$

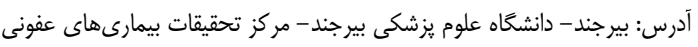

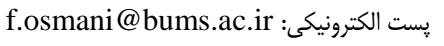

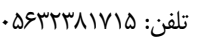




\section{روش تحقيق}

مطالعه حاضر پِ از تأييد شوراى يزوهشى دانشگاه علوم

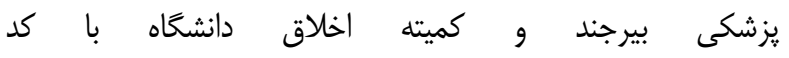
IR.BUMS.REC.1397.076 انجام شد. در اين مطالعه توصيفى مقطعى با استفاده از روش نمونه كَيرى

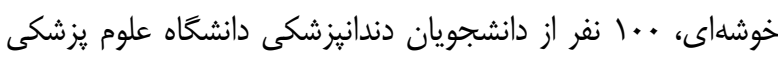

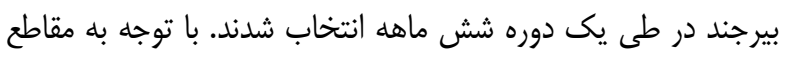

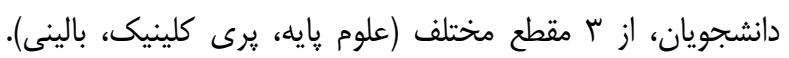

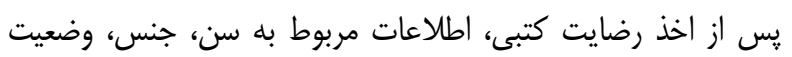
تأهل، مقطع تحصيلى، سابقه مثبت از ابتلا به ضايعات دستخاه

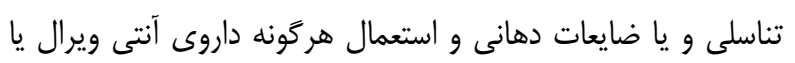

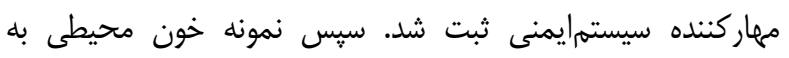

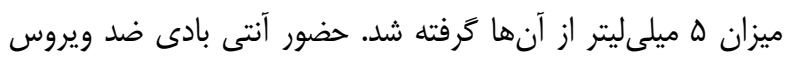

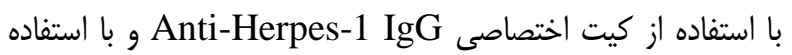
از روش ( Enzyme-Linked Immunosorbent Assay (ELISA

\section{يافته ها}

اين مطالعه بر روى ..1 نفر از دانشجويان دندانيزشكى با بالن ميانخين سنى /

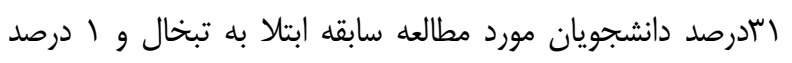

$$
\text { سابقه مصرف داروهاى ضدويروسى داشتند. }
$$

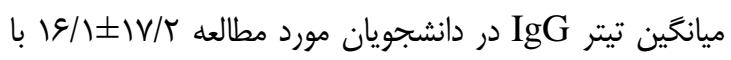

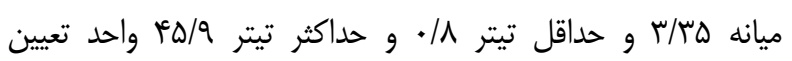

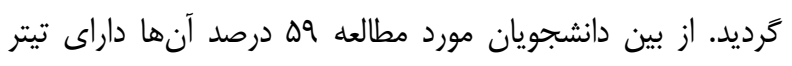

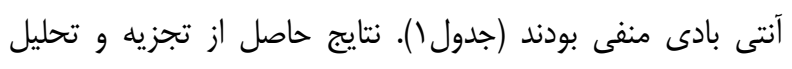

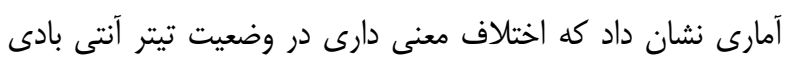
بر حسب جنس، وضعيت تأهل، مقطع تحصيلى وكروه سنى در بين

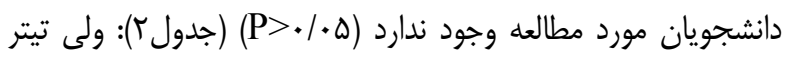

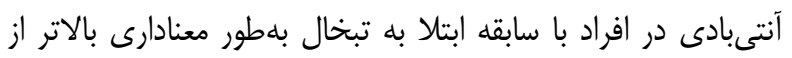

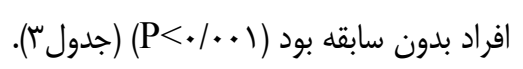

مقدمه

عفونت هريس سيمبلكس از مهمترين و شايع ترين عفونتهاى

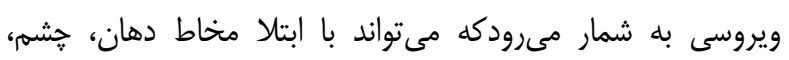

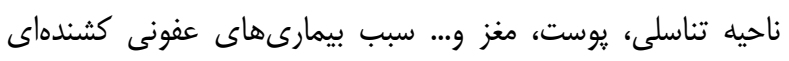

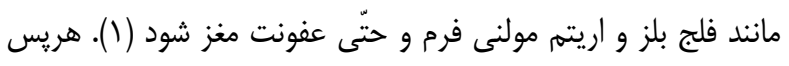

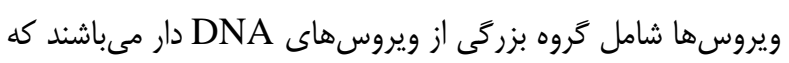

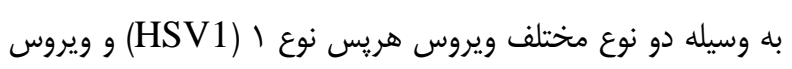

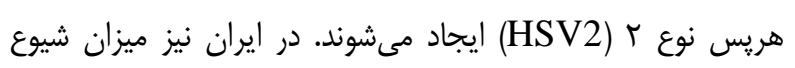
HSV1

احتمال انتقال عفونتهاى متقاطع در حين اعمال دندانيزشكى

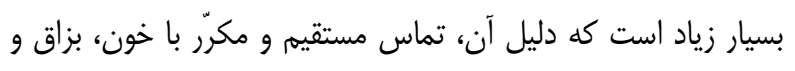
ساير مايعات بدن و تماس غير مستقيم با وسايل و سطوح آلوده و

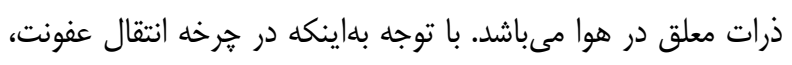

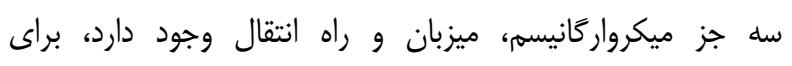

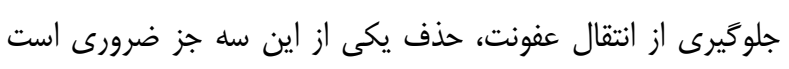

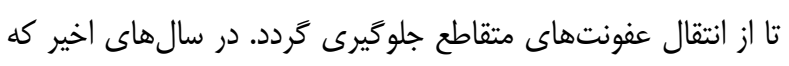

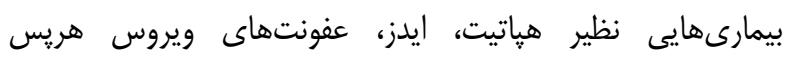
سيميلكس و ساير بيمارىهاى عفونى مطرح شده است، توجه زيادى

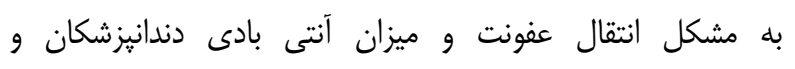

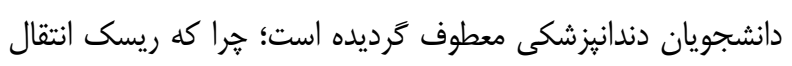

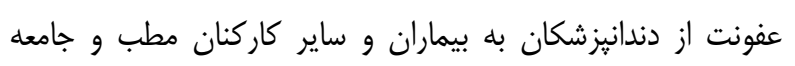
وجود دارد (r). با توجه بهاينكه دانشجويان دندانيزشكى، در حين دوره تحصيل

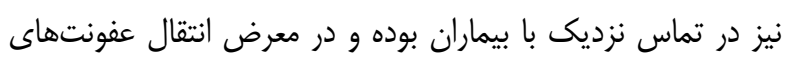

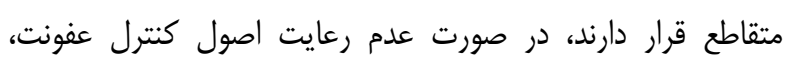

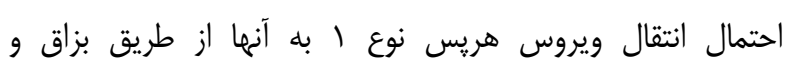

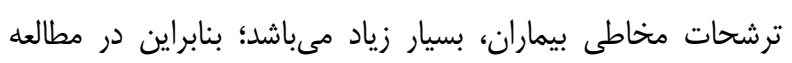

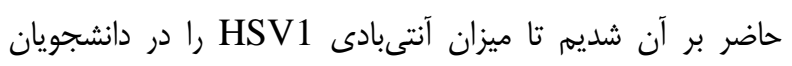
دندانيزشكى بيرجند در سال Vو-عوبا مورد بررسى قرار دهيه. 
جدول ا - توزيع فراوانى تيتر آنتى بادى در دانشجويان مورد مطالعه

\begin{tabular}{|c|c|c|}
\hline درصد & فراوانى & وضعيت تيتر آنتى بادى \\
\hline$\Delta 9$ & $\Delta Q$ & منفى \\
\hline (1) & il & مثبت \\
\hline $1 \ldots$ & $1 \ldots$ & جمع \\
\hline
\end{tabular}

جدول r- مقايسه توزيع فراوانى تيتر آنتى بادى بر حسب جنس و تروه سنى در دانشجويان مورد مطالعه

\begin{tabular}{|c|c|c|c|c|}
\hline كتيجه آزمون آمارى & فراوانى (درصد) & فراوانى (درصد) & \multicolumn{2}{|c|}{ وضعيت تيتر آنتى بادى } \\
\hline \multirow[t]{2}{*}{$\mathrm{P}=\cdot / \mathrm{V}$} & $r \cdot(r \Delta / 1)$ & $\mu v(9 \% / 9)$ & مؤنث & \\
\hline & $r\left(\Psi^{\mathcal{N} N / \Lambda)}\right.$ & $r(\Delta) / T)$ & مذكر & جنسيت \\
\hline \multirow[t]{3}{*}{$\mathrm{P}=\cdot / 9 \mathrm{r}$} & $M\left(\varphi^{\varphi} \cdot\right)$ & $\operatorname{Tr}(\xi \cdot)$ & آ سال و كمتر & \multirow{3}{*}{ كروه سنى } \\
\hline & $I f(F \cdot)$ & $M(\xi \cdot)$ & זr تأب سال & \\
\hline & $9(f \Delta)$ & $\|(\Delta \Delta)$ & هT سال و بيشتر & \\
\hline
\end{tabular}

جدول ب- مقايسه توزيع فراوانى وضعيت تيتر آنتى بادى بر حسب وضعيت تأهل، مقطع تحصيلى و سابقه ابتلا به تبخال

\begin{tabular}{|c|c|c|c|c|}
\hline نتيجه آزمون آمارى & مثبت & منفى & & وضعيت تيتر آنتى بادى \\
\hline & & & & متغير \\
\hline \multirow[t]{2}{*}{$\mathrm{P}=\cdot / \wedge F$} & 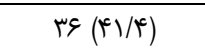 & $\Delta)(\Delta N / \xi)$ & مجرد & وضعيت تأهل \\
\hline & $\Delta(\mu N / \Delta)$ & $\wedge(\xi) / \Delta)$ & متأهل & \\
\hline \multirow[t]{3}{*}{$\mathrm{P}=\cdot / \mathrm{VV}$} & 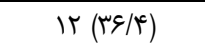 & $r I(\xi \Gamma / q)$ & علوم پايه & مقطع تحصيلى \\
\hline & $\| F(F \Delta / \tau)$ & $\operatorname{IV}(\Delta F / \Lambda)$ & يره كلينيك & \\
\hline & $10(F) / V)$ & $r(\Delta N / r)$ & بالينى & \\
\hline \multirow[t]{2}{*}{$\mathrm{P}<\cdot / . \cdot 1$} & If $(\Gamma \cdot / r)$ & $\Delta \Delta(\mathrm{V} / \mathrm{V})$ & ندارد & سابقه ابتلا به تبخال \\
\hline & $r \vee(\Lambda \vee / \perp)$ & $r(1 r / 9)$ & دارد & \\
\hline
\end{tabular}

مطالعه تيتر آنتى بادى مثبت داشتند، ساير مطالعات نيز نتايج مشابهى

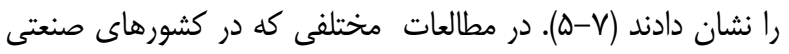

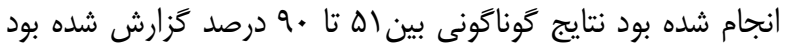

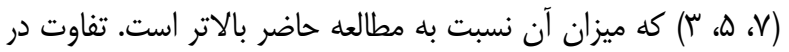

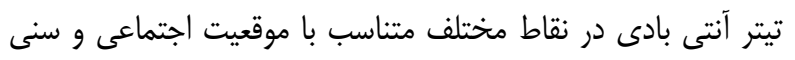
كروه هاى مورد بررسى مى باشد. بر اساس نتايج مطالعه حاضر، ميانخين آنتى بادى HSV1 مرد برد

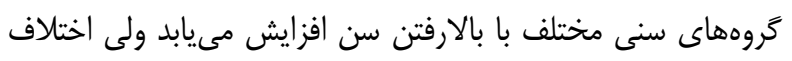

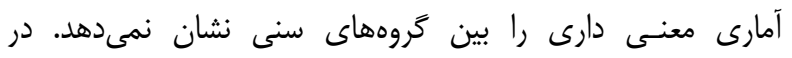

تحقيقات نشان مىدهد كه دندانيزشكان و دستياران شان، پس از ها دقيقه قراركيرى در معرض ايروسلهاى دهانى بيمار قادرند ๔ أ/• ميكروليتر از ايروسلهاى ناشى از بزاق بيمار را استنشاق

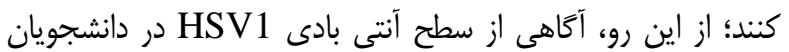

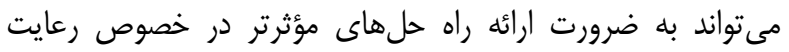

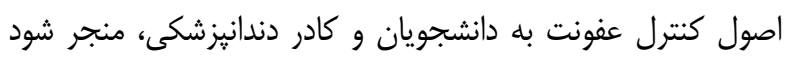

نتايج مطالعه حاضر نشان داد كه اكثريت دانشجويان مورد 
نيز همسو با اين نتيجه بدست آمده از مطالعه حاضر مىباشد. در مطالعه حاضر حدود بيست درصد افرادى كه سابقه تبخال

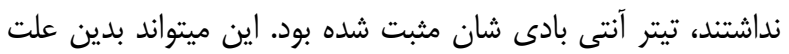

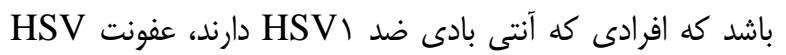
دهانى را در طى دوره كودكى دريافت كرده اند ولى عود مجدد

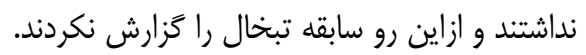

\section{نتيجل كيرى}

توصيه مى شود براى تعيين آَاهى دانشجويان از اصول كنترل

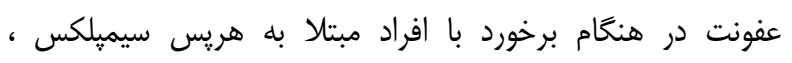

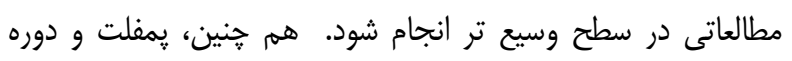

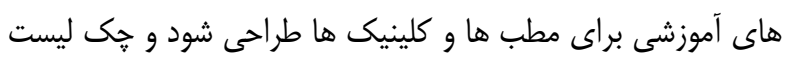
هاى نظارتى وجود داشته باشد.

\section{تقدير و تشكّر}

مقاله فوق مستخرج از پاياننامه دانشجويى با كد يزوهشى:

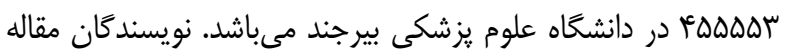
از معاونت تحقيقات و فناورى و همجِنين مركز توسعه تحقيقات

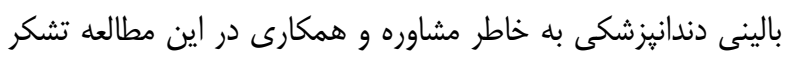

$$
\text { و قدردانى مىنمايند. }
$$

\section{تضاد منافع}

نويسندكان مقاله اعلام مى دارند كه هيج كَونه تضاد منافعى در

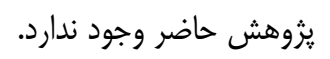

تحقيقات ساير محققين نظير Suligoi در ايتاليا (^)، Tunbäck در سوئد (9)، و Bünzli در سوئيس (•()، افزايش سن را به عنو عنوان

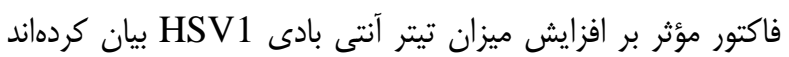
كه مشابه با نتايجاين مطالعه مىباشد. مى توان افزايش ميانكَين تيتر

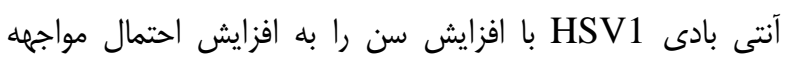

$$
\text { ويروس را با افزايش سن نسبت داد. }
$$

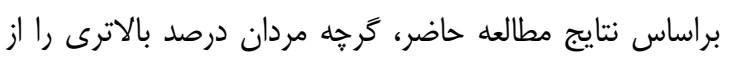
نظر آنتى بادى IgG نسبت به زنان به خود اختصاص داديج دادند؛ ولى داصلى

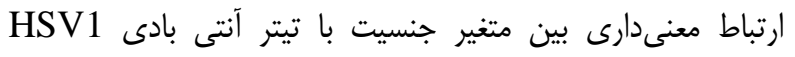

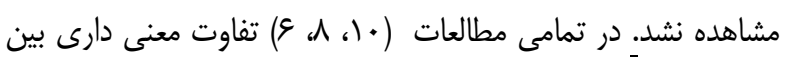

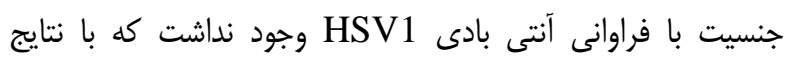
مطالعه حاضر هم خوانى دارد. طبق نتايج اين مطالعه شيوع آنتى بـ بنى بادى در دانشجويان يره كلينيك بالاتر از دانشجويان در مقطع علوم داني

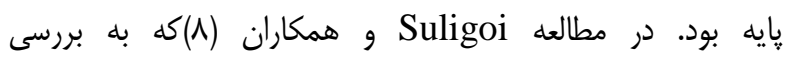
سروإيبدميولوزى ويروس هريس در ميان كاركنان و دانشجويان

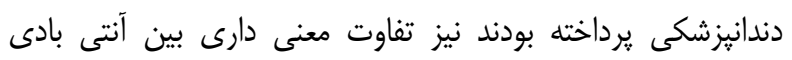
HSV1 بادى در دانشجويان در مقطع بالينى بيشتر از مقطع يره كلينيك بود دان

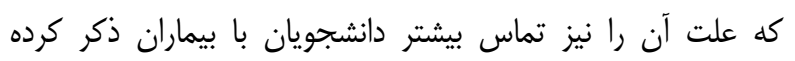

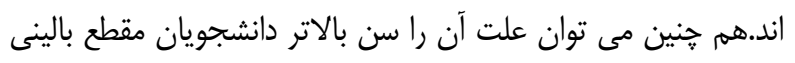

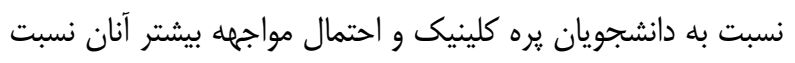
به ويروس دانست.

هم جنين، بين شيوع آنتى بادى HSV1 با وضعيت تأناتهل

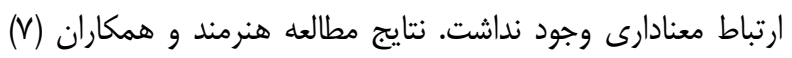

1- Molinari JA. Dental infection control at the year 2000: accomplishment recognized. J Am Dent Assoc. 1999; 130(9): 1291-1298. DOI: 10.14219/jada.archive.1999.0399

2- Malary M, Abedi G, Hamzehgardeshi Z, Afshari M, Moosazadeh M., The prevalence of herpes simplex virus type 1 and 2 infection in Iran: A meta-analysis. Int J Reprod Biomed. 2016; 14(10): 615-24. Link DOI: $10.5812 / \mathrm{ijcm} .110452$

3- Petti S, Lodi G. The controversial natural history of oral herpes simplex virus type 1 infection. Oral Dis. 2019; 25(8): 1850-65. DOI: 10.1111/odi.13234 
4- Lee A, Hong J, Shin DY, Koh Y, Yoon SS, Kim PJ,et al. Association of HSV-1 and Reduced Oral Bacteriota Diversity with Chemotherapy-Induced Oral Mucositis in Patients Undergoing Autologous Hematopoietic Stem Cell Transplantation. J Clin Med. 2020; 9(4): 1090. DOI: 10.3390/jcm9041090

5- Brooks SL, Rowe NH, Drach JC, Shipman C, Young SK. Prevalence of herpes simplex virus disease in a professional population. J Am Dent Assoc. 1981; 102(1): 31-4. DOI: 10.14219/jada.archive.1981.0017.

6- Parvaie P, Majd HS, Ziaee M, Sharifzadeh G, Osmani F. Evaluation of gum health status in hemophilia patients in Birjand (a case-control study). Am J Blood Res. 2020; 10(3): 54. PMID: 32685260

7- Honarmand M, Ramazani N. Recurrent Herpes Labialis in Children and Dental Health Workers. Int J Pediatr. 2021; 9(3): 13113-5. DOI: 10.22038/IJP.2021.55262.4355

8- Suligoi B, Torri A, Grilli G, Tanzi E, Palù G. Seroprevalence and seroincidence of herpes simplex virus type 1 and herpes simplex virus type 2 infections in a cohort of adolescents in Italy. Sex Transm Dis. 2004; 31(10): 608-10. DOI: 10.1097/01.olq.0000140013.60224.ba

9- Tunbäck P, Bergström T, Andersson AS, Nordin P, Krantz I, Löwhagen GB. Prevalence of herpes simplex virus antibodies in childhood and adolescence: a cross-sectional study. Scand J Infect Dis. 2003; 35(8): 498-502. DOI: $10.1080 / 00365540310013018$

10- Bünzli D, Wietlisbach V, Barazzoni F, Sahli R, Meylan PR. Seroepidemiology of Herpes Simplex virus type 1 and 2 in Western and Southern Switzerland in adults aged 25-74 in 1992-93: a population-based study. BMC Infect Dis. 2004; 4(1): 1-2. DOI: 10.1186/1471-2334-4-10 